University of Nebraska - Lincoln

DigitalCommons@University of Nebraska - Lincoln

\title{
Alien dominance of the parasitoid wasp community along an elevation gradient on Hawai'i Island
}

Robert W. Peck

U.S. Geological Survey, rpeck@usgs.gov

Paul C. Banko

U.S. Geological Survey

Marla Schwarzfeld

U.S. Geological Survey

Melody Euaparadorn

U.S. Geological Survey

Kevin W. Brinck

U.S. Geological Survey

Follow this and additional works at: https://digitalcommons.unl.edu/usgsstaffpub

Peck, Robert W.; Banko, Paul C.; Schwarzfeld, Marla; Euaparadorn, Melody; and Brinck, Kevin W., "Alien dominance of the parasitoid wasp community along an elevation gradient on Hawai'i Island" (2008). USGS Staff -- Published Research. 652.

https://digitalcommons.unl.edu/usgsstaffpub/652

This Article is brought to you for free and open access by the US Geological Survey at DigitalCommons@University of Nebraska - Lincoln. It has been accepted for inclusion in USGS Staff -- Published Research by an authorized administrator of DigitalCommons@University of Nebraska - Lincoln. 


\title{
Alien dominance of the parasitoid wasp community along an elevation gradient on Hawai'i Island
}

\author{
Robert W. Peck · Paul C. Banko • \\ Marla Schwarzfeld · Melody Euaparadorn • \\ Kevin W. Brinck
}

Received: 7 December 2007 / Accepted: 21 January 2008/Published online: 6 February 2008

(C) Springer Science+Business Media B.V. 2008

\begin{abstract}
Through intentional and accidental introduction, more than 100 species of alien Ichneumonidae and Braconidae (Hymenoptera) have become established in the Hawaiian Islands. The extent to which these parasitoid wasps have penetrated native wet forests was investigated over a 1,765 $\mathrm{m}$ elevation gradient on windward Hawai' $i$ Island. For $>1$ year, malaise traps were used to continuously monitor parasitoid abundance and species richness in nine sites over three elevations. A total of 18,996 individuals from 16 subfamilies were collected. Overall, the fauna was dominated by aliens, with 44 of 58 species foreign to the Hawaiian Islands. Ichneumonidae was dominant over Braconidae in terms of both diversity and abundance, comprising $67.5 \%$ of individuals and $69.0 \%$ of species collected. Parasitoid abundance and species richness varied significantly with elevation: abundance was greater at mid and high elevations compared to low elevation while species richness
\end{abstract}

R. W. Peck $(\bowtie) \cdot$ M. Schwarzfeld · M. Euaparadorn ·

K. W. Brinck

Hawai'i Cooperative Studies Unit, U.S. Geological Survey, University of Hawai'i at Hilo/PACRC, Kīlauea Field Station, P.O. Box 44, Hawai'i National Park, HI 96718, USA

e-mail: rpeck@usgs.gov

P. C. Banko

Pacific Island Ecosystems Research Center, U.S. Geological Survey, Kîlauea Field Station, P.O. Box 44, Hawai'i National Park, HI 96718, USA increased with increasing elevation, with all three elevations differing significantly from each other. Nine species purposely introduced to control pest insects were found, but one braconid, Meteorus laphygmae, comprised $98.0 \%$ of this assemblage, or $28.3 \%$ of the entire fauna. Endemic species, primarily within the genera Spolas and Enicospilus, were collected almost exclusively at mid- and high-elevation sites, where they made up $22.1 \%$ and $36.0 \%$ of the total catch, respectively. Overall, $75.9 \%$ of species and $96.0 \%$ of individuals are inferred to parasitize Lepidoptera larvae and pupae. Our results support previous data indicating that alien parasitoids have deeply penetrated native forest habitats and may have substantial impacts on Hawaiian ecosystems.

Keywords Alien species - Biological control . Braconidae · Elevation gradient · Ichneumonidae . Hawai'i · Parasitism

\section{Introduction}

Among the more damaging insects to have invaded Hawaiian ecosystems are parasitoid wasps within the superfamily Ichneumonoidea. These wasps lay their eggs inside, on, or near the eggs, larvae, or pupae of their arthropod hosts, ultimately resulting in host death. The host may be immobilized or killed at the time that the parasitoid lays its eggs, or it may survive until the late stages of development. Because most 
parasitoids are small insects that do not attack humans or other vertebrates, their potential impacts on host populations and ecosystem tend to be overlooked by natural area managers and conservation biologists. In contrast, agriculturalists and foresters generally regard parasitoids as beneficial because they attack many insect pests of crops and timber. Our research describes the distribution and abundance of alien and endemic species of ichneumonoid parasitoids in a Hawaiian rain forest as the first step in evaluating their impacts on native insect populations, food webs, and ecosystems.

The Ichneumonoidea is a diverse group of parasitic Hymenoptera, consisting of nearly 100,000 species worldwide (Wahl and Sharkey 1993). The two families making up this group, the Ichneumonidae and Braconidae, parasitize a wide range of holometabolous arthropods, including Lepidoptera, Diptera, Coleoptera, and some Heteroptera (Askew 1971). Life-histories of parasitoid hosts vary widely and include species that feed exposed on vegetation as well as those that feed concealed within plant tissues (e.g. seeds, fruit, wood) or surrounded by protective casings. Studies of Ichneumonidae indicate that species richness is generally highest at mid latitudes (Owen and Owen 1974; Janzen and Pond 1975; Janzen 1981) but recent work challenged this generalization, suggesting that the tropics are as rich as temperate areas, at least for some subfamilies (Gauld 1986, 1987; Gaston and Gauld 1993; Sääksjärvi et al. 2004).

Extreme isolation of the Hawaiian Islands has resulted in an arthropod fauna that is characteristically depauperate at higher taxonomic levels, with ants, cockroaches, termites and some other globally widespread groups naturally absent from the archipelago (Zimmerman 1948). Only five of the world's 64 subfamilies of Ichneumonoidea are represented in Hawai'i by endemic species (Sharkey 1993; Wahl 1993). Endemic Hawaiian Ichneumonidae are distributed in the Ophioninae (24 species), Anomaloninae (11 species), and Pimplinae (three species), while Hawaiian Braconidae are found in the Pambolinae (two species) and Alysiinae (one species) (Nishida 2002). The status of several other species of Ichneumondae are unknown and may also be endemic. All Hawaiian Ichneumonidae attack Lepidoptera, while the single member of the Alysiinae attacks muscid and sarcophagid flies (Diptera); hosts of Hawaiian Pambolinae are unknown (Beardsley 1961).

Since Western contact with the Hawaiian Islands in 1778, the number of Ichneumonoidea has increased dramatically through accidental and intentional introduction. Currently, more than 100 species have become established, 40 of which were released as biocontrol agents (Funasaki et al. 1988; Nishida 2002). Efforts to establish Ichneumonoidea for biocontrol have taken place throughout the 20th century with at least 20 species released each decade between 1900 and 1989 (Follett et al. 2000). Much recent discussion has drawn attention to the potential impact of alien parasitoids on Hawai'i's native fauna, with most of the focus being on biocontrol agents (Howarth 1983, 1991; Gagné and Howarth 1982; Funasaki et al. 1988; Follett and Duan 1999; Follett et al. 2000; Johnson et al. 2005).

This study was designed to complement the recent emphasis in Hawai'i on measuring rates of parasitism by alien parasitoids (Henneman and Memmott 2001; Brenner et al. 2002; Oboyski et al. 2004; Johnson et al. 2005) by determining the distribution and relative abundance of alien and native Ichneumonoidea at the landscape level. To do this, we surveyed the parasitoid fauna within native wet forests ranging from coastal to montane sites on Hawai'i Island. Our primary objectives were to identify the extent to which alien parasitoids have penetrated native forests and to determine whether a relationship exists between alien parasitoid abundance and elevation. Low-elevation forests are expected to be most susceptible to invasion by alien parasitoids because their structure and composition is generally more disturbed, they are closer to agricultural lands that potentially harbor pest Lepidoptera, and they are closer to points of introduction. Other studies have shown that alien arthropod abundance and diversity decreases with increasing elevation in Hawai'i (Gagné 1979; USGS unpublished data).

\section{Methods and materials}

Study area

Study sites were located on the wet, windward slopes of the geologically active Kîlauea and Mauna Loa volcanoes, Hawai'i Island. All sites were previously 
Table 1 Attributes of wet forest sites surveyed for Ichneumonidae and Braconidae using malaise traps on Hawai'i Island

\begin{tabular}{|c|c|c|c|c|c|c|c|}
\hline \multirow[t]{2}{*}{ Site name } & \multirow{2}{*}{$\begin{array}{l}\text { Name } \\
\text { code }\end{array}$} & \multirow{2}{*}{$\begin{array}{l}\text { Latitude (N), } \\
\text { Longitude (W) }\end{array}$} & \multirow{2}{*}{$\begin{array}{l}\text { Elevation } \\
(\mathrm{m})\end{array}$} & \multirow{2}{*}{$\begin{array}{l}\text { Estimated } \\
\text { annual } \\
\text { rainfall } \\
(\mathrm{mm})^{\mathrm{a}}\end{array}$} & \multirow{2}{*}{$\begin{array}{l}\text { Substrate } \\
\text { age (years) }\end{array}$} & \multicolumn{2}{|c|}{ Plant species richness ${ }^{\mathrm{c}}$} \\
\hline & & & & & & Alien & Native \\
\hline Malama-Kī Forest Reserve & MAL & $19^{\circ} 26^{\prime} 33^{\prime \prime}, 154^{\circ} 51^{\prime} 36^{\prime \prime}$ & 27 & 2,250 & 215 & 20 & 13 \\
\hline Nānāwale Forest Reserve & NAN & $19^{\circ} 32^{\prime} 07^{\prime \prime}, 154^{\circ} 53^{\prime} 44^{\prime \prime}$ & 73 & 3,100 & 165 & 21 & 23 \\
\hline Bryson's & BRY & $19^{\circ} 27^{\prime} 01^{\prime \prime}, 154^{\circ} 55^{\prime} 47^{\prime \prime}$ & 285 & 3,000 & $750-1,500$ & 30 & 17 \\
\hline $\begin{array}{l}\text { Waiākea Forest } \\
\text { Reserve }\end{array}$ & WAI & $19^{\circ} 36^{\prime} 35^{\prime \prime}, 155^{\circ} 13^{\prime} 32^{\prime \prime}$ & 1,000 & 4,600 & $1,500-3,000$ & 9 & 23 \\
\hline Cooper Center & $\mathrm{COO}$ & $19^{\circ} 26^{\prime} 37^{\prime \prime}, 155^{\circ} 13^{\prime} 46^{\prime \prime}$ & 1,112 & 3,300 & $400-750$ & 5 & 25 \\
\hline Crater Rim & CRA & $19^{\circ} 24^{\prime} 24^{\prime \prime}, 155^{\circ} 14^{\prime} 47^{\prime \prime}$ & 1,164 & 2,850 & 215 & 7 & 17 \\
\hline Pu'u Unit & PUU & $19^{\circ} 29^{\prime} 49^{\prime \prime}, 155^{\circ} 15^{\prime} 48^{\prime \prime}$ & 1,306 & 2,900 & $1,500-3,000$ & 2 & 29 \\
\hline CJ Ralph & CJR & $19^{\circ} 31^{\prime} 01^{\prime \prime}, 155^{\circ} 19^{\prime} 52^{\prime \prime}$ & 1,725 & 2,200 & $3,000-5,000$ & 7 & 22 \\
\hline Solomon's Waterhole & SOL & $19^{\circ} 32^{\prime} 20^{\prime \prime}, 155^{\circ} 19^{\prime} 50^{\prime \prime}$ & 1,792 & 2,400 & $1,500-3,000$ & 4 & 27 \\
\hline
\end{tabular}

a Giambelluca et al. 1986

b Wolfe and Morris 1996

c USGS unpublished data

established as part of a larger study investigating the biocomplexity of avian diseases (see Woodworth et al. 2005 for a general description). Nine sites, representing three broad elevation bands, were sampled: three sites at low elevation (27-285 m); four sites at mid elevation (1,000-1,306 m), and two sites at high elevation (1,725-1,792 m) (Table 1). All sites were dominated by Metrosideros polymorpha Gaud ('ōhi'a), the most abundant and widespread canopyforming tree in Hawai'i. Plant composition varied with elevation and substrate age but was generally most diverse at low elevations; alien species, however, contributed greatly to overall floral richness at low elevation, comprising an average of $57.2 \%$ of the richness compared to $22.9 \%$ and $18.5 \%$ at mid and high elevations, respectively (Table 1 ). The topography at all sites consisted of gentle slopes, representative of the geologically young shield volcanoes of Hawai'i Island. Rainfall was strongly influenced by prevailing trade winds, resulting in precipitation throughout the year. Mean annual rainfall ranged from 2,200 to $4,600 \mathrm{~mm}$, and was greatest at mid elevations where orographic effects are strongest (Table 1). Mean daily temperatures vary relatively little at any one site over the course of the year, but decrease with increasing elevation at a rate of approximately $6.5^{\circ} \mathrm{C}$ per $1,000 \mathrm{~m}$ below $1,240 \mathrm{~m}$ and $4.0^{\circ} \mathrm{C}$ per $1,000 \mathrm{~m}$ at higher elevations (Juvik and Juvik 1998). Feral pigs (Sus scrofa), which are a common alien modifier of Hawaiian wet forests, had been removed for management purposes from Hawai'i Volcanoes National Park's Pu'u Unit (PUU) and Crater Rim (CRA) sites approximately 18 year prior to this study.

\section{Arthropod sampling}

Ichneumonoidea were collected using green bidirectional Townes-style malaise traps (Townes 1972) fitted with polyethylene collecting jars (BioQuip Products, Gardena, CA, USA) that were partially filled with the preservative, ethylene glycol (50\%). The malaise trap is widely recognized as an effective method of sampling ichneumonid and braconid communities (Owen et al. 1981; Noyes 1989). Like most trapping methods, malaise traps have biases and constraints, including differential effectiveness among species, and their efficacy is influenced by trap design (e.g. mesh size, color), placement relative to habitat structure, and wind direction (Townes 1972; Mathews and Mathews 1983; Darling and Packer 1988). Because the traps passively intercept flying insects, they more accurately measure flight activity rather than absolute abundance. In spite of these caveats, we consider malaise traps to be an appropriate tool for surveying and comparing the Ichneumonoidea fauna among sites. 
At each site, three traps were placed on the ground or on $\operatorname{logs}$ at random directions 100-200 m apart along pre-existing transects. Traps were run continuously throughout the study period, which spanned 24 March 2003 to 30 August 2004. However, logistical constraints required traps to be set up, maintained, and taken down at slightly different times, so the number of trap-days varied among sites. The number of trap-days for each site was as follows: $\mathrm{MAL}=429 ; \quad \mathrm{NAN}=375 ; \quad \mathrm{BRY}=398 ; \quad \mathrm{WAI}=$ 390; $\quad \mathrm{COO}=509 ; \quad \mathrm{CRA}=509 ; \quad \mathrm{PUU}=373 ;$ $\mathrm{CJR}=521 ; \mathrm{SOL}=521$. Traps were emptied at approximately 30-day intervals. In the lab, samples were transferred to EtOH (70\%) for storage. Representative individuals were later point-mounted on pins for identification.

To provide insight into possible mechanisms driving parasitoid abundances and their effects on the arthropod community, Lepidoptera adults and larvae were collected from Metrosideros foliage within eight of the nine study sites (BRY was not sampled because the canopy was inaccessible). During 17 March-7 July 2004 and 28 September12 November 2004, 15 trees from each site were sampled. Trees were chosen using several methods. On sites with trees of low stature that could be sampled from the ground (MAL, NAN), we randomly selected 15 out of 100 fixed stations on each sample date (all stations were at least $50 \mathrm{~m}$ apart) and sampled the tree nearest the selected station. We then randomly sampled from either the upper or lower half of the canopy and from one of four $90^{\circ}$ quadrants. Samples were obtained using two extendable poles manipulated in concert: one pole was used to clip the branch, dropping it into a nylon bag (approximately $75 \mathrm{~cm}$ diameter by $90 \mathrm{~cm}$ deep) suspended from a metal hoop held by a second pole. The bag was quickly sealed once the branch had dropped. On sites where the canopy was accessible only by climbing (COO, PUU, WAI), trees were randomly selected from a subset of trees in which the canopy could be accessed. Whenever possible, we sampled tall and short trees in the same manner. Trees were generally climbed using spurs and single rope techniques (Laman 1995). Within-canopy samples were obtained using a hand-held clipper and the hoop-suspended bagging apparatus described above, but without the pole. Sites at CRA, CJR and SOL contained a mixture of short and tall trees and were sampled from the ground or by climbing, using a randomization procedure that combined the choice of fixed stations and climbable trees. For all trees sampled, a single terminal foliage cluster approximately $50 \mathrm{~cm}$ long was collected. Samples were returned to the lab for processing the same day that they were collected. Taxonomic determinations were not made for individual Lepidoptera, but at least 14 species from six families have been recorded on Metrosideros from Hawai'i Island (Zimmerman 1958b, 1978; Swezey 1954).

In the lab, foliage was removed from the bag and shaken vigorously to dislodge Lepidoptera and other arthropods onto a white sheet from which they were collected using an aspirator or forceps. Metrosideros leaves were later plucked from branches, oven-dried at $50^{\circ} \mathrm{C}$ for $48 \mathrm{~h}$, and weighed to the nearest $0.1 \mathrm{~g}$.

Specimen identification

Taxonomic determinations of Ichneumonoidea were based upon existing keys and by comparison to identified material within entomology collections at the B. P. Bishop Museum and the Hawai'i Department of Agriculture, Honolulu. Determinations of nonnative Ichneumonidae were primarily based on the late J. Beardsley's unpublished key. Endemic Enicospilus were identified using Cushman (1944). Little attention has been given to the native genus Spolas since Ashmead (1901) and Perkins (1910) made the first descriptions of the fauna. Because characters used to identify this group are highly variable and descriptions of the fauna are incomplete, we chose only to identify members of this genus to the morpho-species level. Our conservative approach possibly resulted in Spolas sp. 3 representing more than one species. Braconidae were identified using Beardsley's (1961) key to this family in Hawai'i. Nishida (2002) was the authority for species origin: endemic (no species were considered indigenous) or alien (adventive = accidentally introduced; biocontrol = purposely introduced for control of agricultural pests).

\section{Data analysis}

The entire malaise trap dataset, spanning 24 March 2003 to 30 August 2004, was used to generate the 
species list and counts of individuals. However, statistical comparisons among sites were limited to results obtained between 28 July 2003 and 11 August 2004, the earliest and latest dates from which traps were running simultaneously at all sites. To account for occasional loss of data due to disturbance of traps, abundances were standardized among sites by multiplying the average number of individuals captured per trap per day by the total number of trap-days within each trapping period. Standardized log-abundance and species richness were compared among elevations using general linear models that nested site within elevation (Insightful Corporation 1988-2005) followed by simulation-based post-hoc pair-wise comparisons (Edwards and Berry 1987). Statistical significance was set at $\alpha=0.05$ prior to analyses. Values are presented as mean \pm SEM.

In general, Lepidoptera abundances in Metrosideros foliage were low, so we tested the effect of elevation on Lepidotera presence using logistic regression, nesting site within elevation. Metrosideros foliage clusters differed slightly in size, so foliage dry weight was included as a covariate.

\section{Results}

Community composition, abundance, and species richness patterns along the elevation gradient

A total of 18,996 ichneumonoid wasps representing 16 subfamilies and 58 species were collected from the nine sites during 17 months of field collection (Table 2). Of the fauna known from Hawai'i Island, approximately $46 \%$ of the endemic species and $56 \%$ of the alien species were collected. The family Ichneumonidae was dominant over the family Braconidae in both abundance and species richness, comprising $67.5 \%$ of the individuals and $69.0 \%$ of the species. Nevertheless, a braconid, Meteorus laphygmae, was the most abundant species, comprising $28.3 \%$ of the total catch. Next in order of abundance were ichneumonid species: Diadegma blackburni (21.4\% of total), Spolas sp. 3 (15.3\%), Vulgichneumon diminutus (7.3\%), Pimpla punicipes (6.5\%), and Trathala flavoorbitalis (4.9\%). Most other species were rare in the samples, with eight species represented by a single individual, and collectively, 34 species accounting for $<1 \%$ of the total number of individuals trapped.

For the period when all traps operated simultaneously (28 July 2003-11 August 2004), mean abundance of Ichneumonoidea was greatest at mid elevation $(2,557.2 \pm 551.6$ individuals per site), followed by high elevation $(1,692.8 \pm 479.4)$ and low elevation (559.9 \pm 169.3$)$ (Fig. 1a). Among-site differences in mean abundance at each elevation ranged from a factor of 1.8 (high elevation) to 3.4 (low elevation). Despite this variation, there was a statistically significant difference among elevations for the natural logarithm of abundance $\left(F_{2,6}=10.36\right.$, $P=0.01$ ). Post-hoc tests (at $\alpha=0.05$ ) showed high and mid elevation abundances were different from low, but not from each other.

Species richness increased with elevation, with mean values of $11.7( \pm 2.7), 24.5( \pm 1.8)$ and 29.5 $( \pm 0.5)$ for low, mid and high elevations, respectively (Fig. 1b). An overall statistical difference was found among elevations $\left(F_{2,6}=22.62, P<0.01\right)$, with all elevations significantly different from each other. This trend was most pronounced for endemic ichneumonoids, which were represented by only three species at low elevation (Table 3). Low elevation sites also showed the largest range in total richness, with more than twice as many species found at NAN (8) compared to MAL (17). In contrast, richness at mid and high elevations was relatively uniform (ranging from 21 to 28 and 29 to 30 species, respectively). Of the 58 species collected over the course of the study, 25 were found at only one elevation: 13 species were restricted to low sites, four to mid sites, and eight to high sites (Table 2). For these 25 elevation-restricted species, 19 were rare ( $\leq 10$ specimens collected).

Overall, the parasitoid fauna was dominated by aliens, both in terms of number of species $(76.3 \%$ alien) and number of individuals $(75.9 \%$ alien) (Tables 2 and 3; Fig. 1). The low-elevation fauna was almost entirely (98.8\%) comprised of alien individuals, but the proportion of aliens in the catch decreased as elevation increased $(77.9 \%$ at mid elevation and $64.0 \%$ at high elevation). Endemic parasitoid individuals outnumbered aliens at only one mid-elevation (PUU) and one high-elevation (SOL) site. Although the proportion of endemic parasitoids increased with elevation, some mid- and highelevation sites were still dominated by aliens 
Table 2 Abundance of Ichneumonidae and Braconidae collected in malaise traps along an elevation gradient in wet forest sites on Hawai'i Island between 24 March 2003 and 30 August 2004

\begin{tabular}{|c|c|c|c|c|c|c|c|c|c|c|}
\hline \multirow[t]{2}{*}{ Family, subfamily and species } & \multirow[t]{2}{*}{ Status $^{\mathrm{a}}$} & \multicolumn{3}{|c|}{ Low elevation } & \multicolumn{4}{|c|}{ Mid elevation } & \multicolumn{2}{|c|}{ High elevation } \\
\hline & & MAL & NAN & BRY & $\mathrm{COO}$ & CRA & PUU & WAI & CJR & SOL \\
\hline
\end{tabular}

Ichneumonidae

Anomaloninae

Spolas sp. 1

Spolas sp. 2

Spolas sp. 3

Spolas sp. 4

Campopleginae

Casinaria infesta (Cresson)

Diadegma blackburni (Cameron)

Diadegma insularis (Cresson)

Diadegma pattoni (Ashmead)

Eriborus sinicus (Holmgren)

Hyposoter exiguae (Viereck)

Venturia sp.

Cremastinae

Pristomerus hawaiiensis Perkins

Trathala flavoorbitalis (Cameron)

Sp. J

Cryptinae

Gambrus ultimus (Cresson)

Gelis tenellus (Say)

Gotra sp.

Sp. A

Sp. T

Ichneumoninae

Barichneumon californicus Heinrich

Ichneumon cupitus Cresson

Ichneumon sp. nr. laetus Brulle

Ichneumon purpuripennis Cresson

Rubicundiella perturbatrix Heinrich

Vulgichneumon diminutus (Matsumura)

Metopiinae

Triclistus sp.

Ophioninae

Enicospilus dispilus Perkins

Enicospilus hawaiiensis (Ashmead)

Enicospilus lineatus (Cameron)

Enicospilus longicornis Ashmead

Enicospilus molokaiensis Ashmead

Enicospilus nigrolineatus Ashmead

Enicospilus orbitalis (Ashmead)

\begin{tabular}{|c|c|c|c|c|c|c|c|c|c|}
\hline end & 0 & 0 & 0 & 17 & 66 & 40 & 46 & 25 & 264 \\
\hline end & 0 & 0 & 0 & 116 & 28 & 154 & 119 & 14 & 47 \\
\hline end & 0 & 0 & 17 & 242 & 617 & 680 & 220 & 114 & 1,008 \\
\hline end & 0 & 0 & 0 & 2 & 0 & 0 & 0 & 1 & 62 \\
\hline $\mathrm{adv}$ & 0 & 0 & 0 & 0 & 35 & 2 & 2 & 3 & 0 \\
\hline $\mathrm{adv}$ & 0 & 0 & 0 & 776 & 1,286 & 157 & 152 & 552 & 1,147 \\
\hline $\mathrm{adv}$ & 1 & 0 & 0 & 0 & 0 & 0 & 0 & 0 & 0 \\
\hline $\mathrm{adv}$ & 0 & 0 & 0 & 0 & 2 & 0 & 0 & 1 & 35 \\
\hline bio & 0 & 0 & 0 & 1 & 2 & 7 & 1 & 0 & 0 \\
\hline $\mathrm{adv}$ & 0 & 0 & 0 & 0 & 6 & 2 & 0 & 6 & 39 \\
\hline $\mathrm{adv}$ & 30 & 0 & 0 & 0 & 0 & 0 & 0 & 0 & 0 \\
\hline end? & 4 & 0 & 0 & 10 & 85 & 35 & 84 & 15 & 9 \\
\hline $\mathrm{adv}$ & 129 & 685 & 44 & 0 & 12 & 23 & 32 & 0 & 0 \\
\hline $\mathrm{adv}$ & 42 & 0 & 10 & 0 & 0 & 0 & 0 & 0 & 0 \\
\hline $\mathrm{adv}$ & 0 & 0 & 0 & 0 & 0 & 0 & 0 & 5 & 0 \\
\hline $\mathrm{adv}$ & 2 & 0 & 0 & 0 & 0 & 0 & 0 & 1 & 0 \\
\hline $\mathrm{adv}$ & 10 & 0 & 0 & 0 & 0 & 0 & 0 & 0 & 0 \\
\hline $\mathrm{adv}$ & 0 & 0 & 0 & 1 & 3 & 1 & 1 & 17 & 1 \\
\hline $\mathrm{adv}$ & 1 & 0 & 0 & 0 & 0 & 0 & 0 & 0 & 0 \\
\hline $\mathrm{adv}$ & 0 & 0 & 0 & 2 & 12 & 3 & 0 & 17 & 13 \\
\hline $\mathrm{adv}$ & 0 & 0 & 0 & 1 & 84 & 69 & 0 & 100 & 55 \\
\hline $\mathrm{adv} ?^{\mathrm{b}}$ & 0 & 0 & 0 & 0 & 0 & 0 & 0 & 7 & 2 \\
\hline bio & 0 & 0 & 0 & 0 & 0 & 0 & 0 & 0 & 1 \\
\hline $\mathrm{adv}$ & 0 & 0 & 0 & 4 & 13 & 2 & 1 & 8 & 9 \\
\hline $\mathrm{adv}$ & 0 & 0 & 1 & 534 & 253 & 165 & 392 & 27 & 21 \\
\hline $\mathrm{adv}$ & 3 & 2 & 0 & 0 & 1 & 0 & 0 & 0 & 0 \\
\hline end & 0 & 0 & 0 & 0 & 0 & 0 & 0 & 0 & 1 \\
\hline end & 0 & 0 & 0 & 0 & 0 & 3 & 0 & 1 & 21 \\
\hline end & 0 & 0 & 0 & 1 & 1 & 8 & 0 & 0 & 1 \\
\hline nd & 0 & 0 & 0 & 0 & 0 & 0 & 0 & 2 & 1 \\
\hline nd & 0 & 0 & 0 & 2 & 0 & 2 & 1 & 1 & 0 \\
\hline end & 0 & 0 & 0 & 0 & 1 & 0 & 3 & 0 & 0 \\
\hline & 0 & 0 & 0 & 45 & 25 & 51 & 26 & 92 & 62 \\
\hline
\end{tabular}


Table 2 continued

\begin{tabular}{|c|c|c|c|c|c|c|c|c|c|c|}
\hline \multirow[t]{2}{*}{ Family, subfamily and species } & \multirow[t]{2}{*}{ Status $^{\mathrm{a}}$} & \multicolumn{3}{|c|}{ Low elevation } & \multicolumn{4}{|c|}{ Mid elevation } & \multicolumn{2}{|c|}{ High elevation } \\
\hline & & MAL & NAN & BRY & $\mathrm{COO}$ & CRA & PUU & WAI & CJR & SOL \\
\hline \multicolumn{11}{|l|}{ Orthocentrinae } \\
\hline Megastylus flavopictus (Gravenhorst) & $\operatorname{adv}$ & 0 & 0 & 0 & 0 & 0 & 5 & 0 & 0 & 0 \\
\hline \multicolumn{11}{|l|}{ Pimplinae } \\
\hline Calliephialtes grapholithae (Cresson) & $\operatorname{adv}$ & 0 & 2 & 0 & 0 & 0 & 1 & 2 & 1 & 1 \\
\hline Echthromorpha agrestoria fuscator (Fab.) & end & 0 & 0 & 1 & 0 & 0 & 0 & 0 & 0 & 1 \\
\hline Pimpla punicipes Cresson & $\operatorname{adv}$ & 0 & 0 & 56 & 140 & 413 & 124 & 100 & 262 & 138 \\
\hline Pimpla sp. B & $\mathrm{adv}$ & 0 & 0 & 0 & 0 & 2 & 0 & 0 & 1 & 2 \\
\hline Tromatobia ovivora (Boheman) & $\mathrm{adv}$ & 1 & 0 & 0 & 0 & 0 & 0 & 0 & 0 & 1 \\
\hline \multicolumn{11}{|l|}{ Undetermined } \\
\hline Ichneumonidae sp. E & $\mathrm{adv}$ & 0 & 0 & 0 & 0 & 0 & 0 & 0 & 1 & 0 \\
\hline \multicolumn{11}{|l|}{ Braconidae } \\
\hline \multicolumn{11}{|l|}{ Alysiinae } \\
\hline Aphaereta pallipes (Say) & $\mathrm{adv}$ & 0 & 0 & 0 & 170 & 142 & 26 & 85 & 69 & 95 \\
\hline Aspilota konae Ashmead & end & 0 & 0 & 0 & 1 & 1 & 5 & 6 & 0 & 4 \\
\hline \multicolumn{11}{|l|}{ Aphidiinae } \\
\hline Sp. G & $\mathrm{adv}$ & 0 & 0 & 0 & 0 & 3 & 3 & 3 & 27 & 0 \\
\hline Sp. L & $\mathrm{adv}$ & 0 & 0 & 0 & 0 & 0 & 0 & 0 & 26 & 0 \\
\hline \multicolumn{11}{|l|}{ Cheloninae } \\
\hline Chelonus blackburni Cameron & $\mathrm{adv}$ & 5 & 0 & 0 & 0 & 0 & 0 & 0 & 0 & 0 \\
\hline Phanerotoma hawaiiensis Ashmead & bio? & 1 & 0 & 0 & 0 & 0 & 0 & 0 & 0 & 0 \\
\hline \multicolumn{11}{|l|}{ Doryctinae } \\
\hline Ontsira palliatus (Cameron) & $\mathrm{adv}$ & 0 & 10 & 0 & 0 & 0 & 0 & 0 & 0 & 0 \\
\hline Ontsira syagrii (Fullaway) & bio & 0 & 0 & 0 & 3 & 19 & 1 & 22 & 0 & 0 \\
\hline Rhaconotus vagrans (Bridwell) & $\operatorname{adv}$ & 1 & 0 & 2 & 0 & 0 & 0 & 0 & 0 & 0 \\
\hline \multicolumn{11}{|l|}{ Meteorinae } \\
\hline Meteorus laphygmae Viereck & bio & 12 & 17 & 706 & 1,884 & 1,703 & 121 & 568 & 310 & 46 \\
\hline Sp. B & $\operatorname{adv}$ & 1 & 2 & 0 & 6 & 0 & 2 & 3 & 6 & 2 \\
\hline \multicolumn{11}{|l|}{ Microgasterinae } \\
\hline Apanteles trifasciatus Muesebeck & $\mathrm{adv}$ & 1 & 0 & 0 & 1 & 4 & 0 & 0 & 0 & 0 \\
\hline Cotesia marginiventris (Cresson) & bio & 2 & 1 & 0 & 0 & 1 & 0 & 1 & 18 & 3 \\
\hline Sp. S & $\mathrm{adv}$ & 1 & 0 & 0 & 0 & 0 & 0 & 0 & 0 & 0 \\
\hline \multicolumn{11}{|l|}{ Opiinae } \\
\hline Biosteres sp. & bio & 0 & 0 & 5 & 0 & 0 & 0 & 0 & 0 & 0 \\
\hline Opius humilis Silvestri & bio & 0 & 0 & 0 & 0 & 0 & 0 & 0 & 1 & 1 \\
\hline Opius lantanae Bridwell & $\operatorname{adv}$ & 0 & 1 & 0 & 0 & 0 & 0 & 0 & 0 & 0 \\
\hline Psyttalia incisi (Silvestri) & bio & 7 & 0 & 15 & 0 & 0 & 0 & 0 & 0 & 0 \\
\hline
\end{tabular}

The number of trap-days varied among sites and are as follows: $\mathrm{MAL}=429 ; \mathrm{NAN}=375 ; \mathrm{BRY}=398 ; \mathrm{WAI}=390 ; \mathrm{COO}=509$; $\mathrm{CRA}=509 ; \mathrm{PUU}=373 ; \mathrm{CJR}=521 ; \mathrm{SOL}=521$

a Status: adv = adventive, or accidentally introduced; bio = purposely introduced for biocontrol; end = endemic (Nishida 2002)

b Questionable status based on Beardsley and Perreira (2000)

(e.g. $89.0 \%$ at $\mathrm{COO}$ and $84.8 \%$ at CJR). Alien abundance was nearly identical at the two high-elevation sites, but 5.6 times more endemic individuals were trapped at SOL than at CJR, which lowered the proportion of aliens represented at SOL. Nowhere did the richness of endemic species equal that of alien 

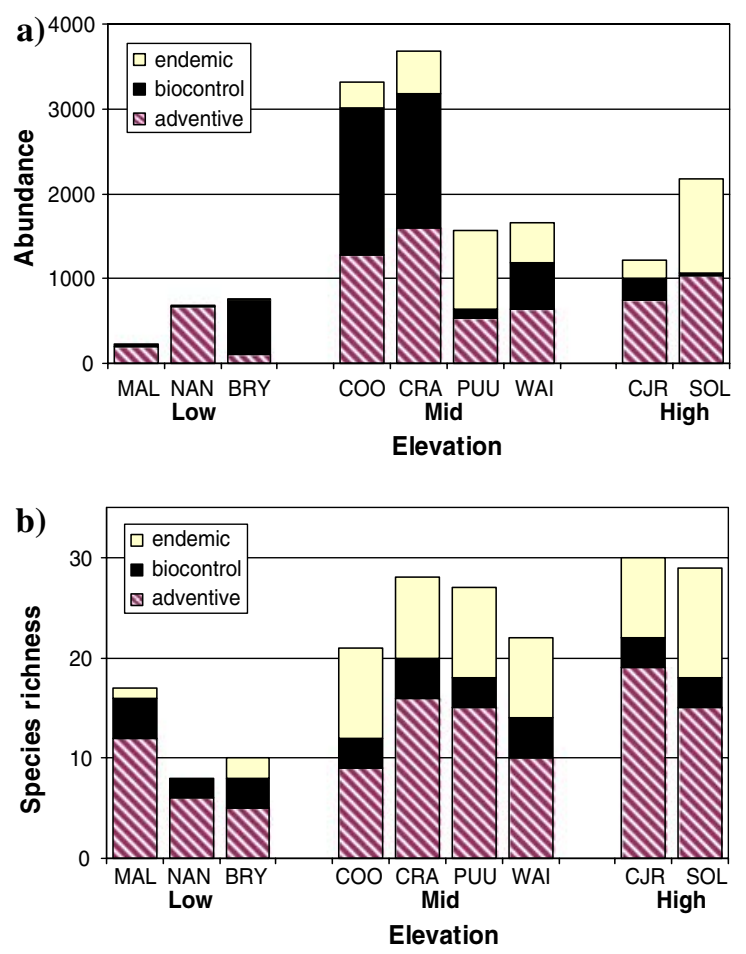

Fig. 1 Total abundance (a) and species richness (b) of endemic and alien (adventive and those purposely introduced for biocontrol) Ichneumonidae and Braconidae collected in wet forest sites on Hawai'i Island between 28 July 2003 and 11 August 2004

species, and no endemic species were collected at one low-elevation site (NAN).

Species of the genus Spolas were the dominant component of the endemic fauna, and two species (unidentified but distinguished as distinct morphotypes) were collected in relatively high numbers at most mid- and high-elevation sites (Table 2). Of the seven species of endemic Enicospilus collected, only E. orbitalis was common, being collected at all midand high-elevation sites.

Five alien species were notably abundant within or across elevations. The introduced braconid, $M$. laphygmae, was the only parasitoid found at all nine sites, and was the most abundant species at three mid-elevation sites and one low-elevation site. Ichneumonid species dominated elsewhere. Trathala flavoorbitalis was the most abundant parasitoid at two low-elevation sites, $V$. diminutus the most common species at one mid-elevation site, and D. blackburni the most common species at both high-elevation sites.
Individuals of nine species introduced to Hawai'i for biological control of agricultural pests comprised $38.0 \%$ of the alien fauna and $28.8 \%$ of all parasitoids. Meteorus laphygmae dominated the biocontrol fauna, comprising $97.9 \%$ of the total. Other species intentionally released for biocontrol applications included the ichneumonids Ichneumon purpuripennis and Eriborus sinicus, and the braconids Ontsira syagrii, Biosteres sp., Opius humilis and Psyttalia incisi. A single specimen of Phanerotoma hawaiiensis was also collected, but its status as an intentional introduction is not firmly established (Nishida 2002).

\section{Host preferences}

Although host ranges of most parasitoids found in our traps are poorly known, in most cases subfamily determinations allowed the host group, at least at the order level, and general life-history, to be inferred. In terms of both species richness and numbers of individuals, the vast majority of the parasitoids collected (75.9\% of species and $96.0 \%$ of individuals) are endoparasitoids of Lepidoptera larvae or pupae (Table 3). In contrast, only 14 species, representing $4.0 \%$ of individuals, attack other host taxa: seven species parasitize Diptera larvae (Megastylus flavopictus, Aphaereta pallipes, Aspilota konae, Biosteres sp., Opius lantanae O. humilis and $P$. incisi), three parasitize Coleoptera larvae (Rhaconotus vagrans, Ontsira palliates and $O$. syagrii), one (Tromatobia ovivora) parasitizes spider eggs, two parasitize aphids (both unidentified morpho-species within Aphidiinae), and one (Gelis tenellus) is a hyperparasitoid of the larvae of other parasitoid Hymenoptera.

\section{Lepidoptera from Metrosideros}

Leaf weight of branch samples did not have a significant effect on Lepidoptera presence, but was retained in the model to account for any variation due to sample size. The rate of Lepidoptera presence within Metrosideros foliage varied significantly among elevations $\left(F_{2,3}=152, \quad P<0.01\right)$, with higher incidence at high elevation compared to either low or mid elevation $(P<0.05)$ (Fig. 2). Rates of low and mid elevations were not distinguishable from each other. On average, 4.8 times more Lepidoptera 
Table 3 Abundance and life-history status of Ichneumonidae and Braconidae collected in wet forests on Hawai'i Island between 24 March 2003 and 30 August 2004

\begin{tabular}{|c|c|c|c|c|c|}
\hline \multirow[t]{2}{*}{ Taxon } & \multicolumn{2}{|c|}{ Number of species } & \multicolumn{2}{|c|}{ Number of individuals } & \multirow[t]{2}{*}{ Life-history $^{\mathrm{a}}$} \\
\hline & Alien & Endemic & Alien & Endemic & \\
\hline \multicolumn{6}{|l|}{ Ichneumonidae } \\
\hline Anomaloninae & 0 & 4 & 0 & 3,899 & Koinobiont endoparasitoids of Lepidoptera larvae \\
\hline Campopleginae & 7 & 0 & 4,245 & 0 & Koinobiont endoparasitoids of Lepidoptera larvae \\
\hline Cremastinae & 2 & 1 & 977 & 242 & Koinobiont endoparasitoids of Lepidoptera larvae \\
\hline \multicolumn{6}{|l|}{ Cryptinae $^{\mathrm{b}}$} \\
\hline Gambrus, Gotra & 2 & 0 & 15 & 0 & Idiobiont ectoparasitoids of Lepidoptera pupae \\
\hline Gelis & 1 & 0 & 3 & 0 & Idiobiont ecto-hyperparasitoid of other Hymenoptera \\
\hline Ichneumoninae & 6 & 0 & 1,796 & 0 & Koinobiont endoparasitoids of Lepidoptera larvae \\
\hline Metopiinae & 1 & 0 & 6 & 0 & Koinobiont endoparasitoid of Lepidoptera larvae \\
\hline Ophioninae & 0 & 7 & 0 & 351 & Koinobiont endoparasitoids of Lepidoptera larvae \\
\hline Orthocentrinae & 1 & 0 & 5 & 0 & Koinobiont endoparasitoid of Diptera (Mycetophilidae) \\
\hline \multicolumn{6}{|l|}{ Pimplinae } \\
\hline Pimpla, Echthromorpha & 2 & 1 & 1,238 & 2 & Idiobiont endoparasitoids of Lepidoptera pupae \\
\hline Calliephialtes & 1 & 0 & 7 & 0 & Idiobiont ectoparasitoid of Lepidoptera larvae or pupae \\
\hline Tromatobia & 1 & 0 & 2 & 0 & Koinobiont ectoparasitoid of spider eggs (Araneidae) \\
\hline \multicolumn{6}{|l|}{ Braconidae } \\
\hline Alysiinae & 1 & 1 & 587 & 17 & $\begin{array}{l}\text { Koinobiont endoparasitoids of Diptera (Cyclorrhapha) } \\
\text { larvae }\end{array}$ \\
\hline Aphidiinae & 2 & 0 & 62 & 0 & $\begin{array}{l}\text { Koinobiont endoparasitoids of Aphidae (Homoptera) } \\
\text { larvae and adults }\end{array}$ \\
\hline Cheloninae & 2 & 0 & 6 & 0 & $\begin{array}{l}\text { Koinobiont endoparasitoids of Lepidoptera eggs and } \\
\text { larvae }\end{array}$ \\
\hline Doryctinae & 3 & 0 & 58 & 0 & $\begin{array}{l}\text { Idiobiont ectoparasitoids of xylophagous and } \\
\text { stem-boring Coleoptera larvae }\end{array}$ \\
\hline Meteorinae & 2 & 0 & 5,389 & 0 & Koinobiont endoparasitoids of Lepidoptera larvae \\
\hline Microgasterinae & 3 & 0 & 33 & 0 & Koinobiont endoparasitoids of Lepidoptera larvae \\
\hline Opiinae & 4 & 0 & 30 & 0 & $\begin{array}{l}\text { Koinobiont endoparasitoids of Diptera (Cyclorrhapha) } \\
\text { larvae }\end{array}$ \\
\hline
\end{tabular}

a Idiobionts kill or immobilize their host upon oviposition while koinobionts allow their host to live as they develop (Askew and Shaw 1986). Parasitoid eggs are generally laid in (endoparasitoids) or on (ectoparasitoids) the bodies of their host

b Life-history status cannot be determined for two unidentified species within this subfamily

were found at high elevation than at mid elevation and 8.3 times more at high than at low elevation. Lepidoptera include both larvae and adults, but larvae comprised $70.0 \%$ of the individuals collected.

\section{Discussion}

Our study is the first in Hawai'i to systematically examine parasitoid community composition and structure along a substantial elevation gradient in wet forests dominated by native vegetation. Our results are significant because they describe landscape level patterns of invasion of alien parasitoid species, which helps to build an appreciation of the potential impacts of alien parasitoids on native arthropods, food webs, and ecosystems. Our study also contributes to knowledge about the spread, abundance, and persistence of biocontrol agents in habitats that are far removed from sites of their introduction. Overall, these results provide further evidence that endemic Lepidoptera larvae are being parasitized to a high degree in a wide range of habitats in Hawai'i. 


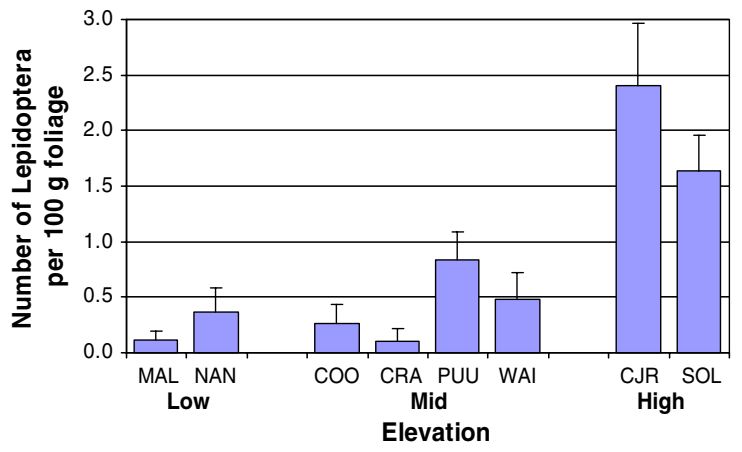

Fig. 2 Mean $( \pm$ SEM) abundance of Lepidoptera collected in Metrosideros polymorpha foliage at low, mid and high elevation wet forest sites on Hawai'i Island

\section{Composition of the parasitoid community}

Alien parasitoids in the families Ichneumonidae and Braconidae were abundant in comparison to native species throughout most of the relatively intact, wet Metrosideros forest that extended along a $1,765 \mathrm{~m}$ gradient of elevation on the windward side of Hawai'i Island. Comparable data are scant in Hawai' $i$, but our results are broadly consistent with those of a few other studies. In a large-scale rearing study, Henneman and Memmott (2001) found alien Braconidae and Ichneumonidae to be the dominant parasitoids emerging from Lepidoptera larvae collected in native wet forests within the Alaka'i Swamp Wilderness of Kaua'i. Also on Kaua'i, but at a slightly more mesic site, Asquith and Miramontes (2001) found that aliens comprised 9 of 17 species, and $90 \%$ of individuals of Ichneumonidae and Braconidae collected in a malaise trap monitored for 2 years. Additionally, within subalpine native woodlands on Mauna Kea Volcano, Hawai'i Island, alien species were major parasitoids of Cydia (Lepidoptera: Tortricidae) larvae within māmane (Sophora chrysophylla) seed pods (Brenner et al. 2002; Oboyski et al. 2004). Collectively, therefore, research is demonstrating that alien parasitoids have penetrated and are dominating a wide range of native forests in Hawai'i.

We collected approximately $50 \%$ of the endemic and alien species known from Hawai'i Island. Proportions of alien species varied according to whether they were adventive $(62 \%)$ or introduced for biocontrol (32\%). For those species that we did not collect, it is unclear whether they were restricted to habitats or hosts found outside the range of our study or were missed due to insufficient sampling. Undoubtedly, many species are rare in space or time and maintain patchy distributions.

The great majority of parasitoids collected in this study attack larvae or pupae of Lepidoptera, although a few species attack immature stages of Coleoptera, Diptera, Aphididae (Homoptera) and spiders (Araneae). The most abundant alien species, which dominated parasitoid communities at all elevations, share the trait of being generalist foragers, attacking a wide range of native and alien Lepidoptera species within multiple host families in Hawai'i. For example, M. laphygmae, the most abundant parasitoid collected, has been recorded from at least 18 species (two endemic) in six families (Zimmerman 1958a, b; Funasaki et al. 1988; Asquith and Miramontes 2001; Henneman and Memmott 2001). Similarly, D. blackburni, which primarily attacks Lepidoptera larvae concealed within plant tissues, and the most abundant parasitoid at high elevation, has been reared from 21 species (18 endemic) within six families (Zimmerman 1958b, 1978; Asquith and Miramontes 2001). And T. flavoorbitalis, the most abundant species at low elevations, has been found to parasitize 34 species (20-22 endemic) in 10 families (Zimmerman 1978; Asquith and Miramontes 2001). Since our knowledge of parasitoid host range is poor for most of the species collected in this study, the diversity of hosts is surely much greater than currently recognized. The ability of a parasitoid to attack a wide range of hosts was a trait sought by early biocontrol practitioners (Williams 1931; Howarth 1983), and undoubtedly, has led to the success of many accidentally introduced parasitoids as well.

Elevation effects on distribution and abundance

A variety of physical and ecological factors likely contributed to the observed patterns associated with elevation. At the low-elevation sites MAL and NAN, the young lava flows (215 and 165 year, respectively) support relatively low plant biomass (USGS unpublished data) and a high proportion of alien plant species, probably resulting in low availability of substrates for parasitoid hosts. The substrate at the low-elevation site BRY is considerably older (750$1,500 \mathrm{yrs}$ ), and in contrast, supports a well-developed 
understory; however, BRY is dominated by nonnative plants (30 of 47 species are alien), which may result in low richness of Lepidoptera, and consequently, explain the low richness of the parasitoid community. Significantly, alien ants, such as the yellow crazy ant (Anoplolepis gracilipes), are abundant throughout the lower elevations of the study area (USGS unpublished data), and may have had direct or indirect negative impacts on the parasitoid fauna. This ant, introduced to the Hawaiian Islands in 1952, has likely reduced native arthropod abundance and diversity in Hawai'i (Gillespie and Reimer 1993) as it has elsewhere (Haines et al. 1994; Green et al. 1999; Lester and Tavite 2004). Moreover, the highly aggressive big-headed ant (Pheidole megacephala), which has decimated low-elevation arthropod communities in Hawai'i since at least the early 1900's (Zimmerman 1978), may have impacted the site prior to the arrival of $A$. gracilipes. Pheidole megacephala was not collected at our low-elevation sites, possibly because it has been displaced by A. gracilipes (Fluker and Beardsley 1970). Fortunately, these and other aggressive ants have not become established in our mid- and high-elevation sites (USGS unpublished data).

In contrast to low elevation, the greater abundance and richness of parasitoids at mid elevation is probably due to the dominance of native plants that support a richer Lepidoptera fauna. The higher overall abundance of parasitoids at COO and CRA compared to PUU and WAI was primarily driven by two species, one purposely introduced (M. laphygmae) and one of adventive origin (D. blackburni). It is unclear why the abundance of these two species varied so greatly, but PUU and WAI may support fewer hosts or environmental conditions may be less favorable.

In general, patterns of parasitoid abundance were inversely related to Lepidoptera abundance on Metrosideros at mid-elevation sites, as more than 3.5 times more Lepidoptera were found at PUU and WAI compared to COO or CRA. If the pattern of Lepidoptera abundance on Metrosideros is representative of other plant species, it suggests that Lepidoptera larvae are being parasitized at much higher rates at COO and CRA than at PUU or WAI. Unfortunately, host associations for M. laphygmae and D. blackburni, as well as overall Lepidoptera diversity and abundance, are too poorly known to speculate on differential rates of parasitism among sites.

Although numbers of alien parasitoids were nearly identical at the two high-elevation sites, disparities in abundances of all four morpho-species of endemic Spolas resulted in greater overall parasitoid numbers at SOL compared to CJR. This result may be attributed to historical differences in disturbance at the two sites. Unlike SOL, CJR has been heavily grazed by cattle and selectively logged, resulting in a more open forest structure with large areas dominated by alien kikuyu grass (Pennisetum clandestinum). Reduced coverage of native understory plants at CJR may have resulted in lower abundances of Lepidoptera important to Spolas. Unfortunately, host associations for Spolas are almost completely unknown. In contrast, endemic Enicospilus commonly attack late instars of Lepidoptera, such as Scotorythra (Geometridae), that are commonly associated with the canopy-forming Metrosideros and Acacia koa that dominate the stands (Zimmerman 1958a).

Avenues of introduction

Alien parasitoids have arrived in Hawai'i either by intentional introduction for biological control of agricultural pests or accidentally through shipping. Between 1890 and 1985, 38 species of braconid or ichneumonid wasp were purposely released in Hawai'i for the first time or, on occasion, to augment existing, accidentally introduced populations (e.g. Diadegma insularis; Johnson et al. 1988; Funasaki et al. 1988). While the current status of some of these species is unknown, many are now widely distributed around the state (Nishida 2002). Meteorus laphygmae, the most abundant parasitoid collected in this study, and the only species found on all nine study sites, was released in 1942 to control noctuid moth larvae infesting sugarcane (Funasaki et al. 1988). It is clearly widespread on Hawai'i Island, having been found in habitats ranging from near sea level (this study) to subalpine woodlands on Mauna Kea (Oboyski et al. 2004, USGS unpublished data). It was also the most abundant species reared from caterpillars on Kaua'i (Henneman and Memmott 2001). Its success may also be attributed to a presumed ability to attack a range of larval instar 
stages, as is done by its congener, M. cinctellus (Munro and Henderson 2002).

In contrast, the other eight biocontrol agents collected in our study were uncommon, comprising $0.5 \%$ of the total fauna. Only the braconid $O$. syagrii (Doryctinae), introduced in 1921 to control the Australian fern weevil (Syagrius fulvitarsis) (Funasaki et al. 1988), can be considered other than rare in the traps. This species was largely restricted to two mid-elevation sites where native tree ferns (Dicksoniaceae: Cibotium spp.) were abundant. It is not known to what extent the target species, or the native weevil fauna, is attacked by this parasitoid.

Accidentally introduced parasitoids likely first began arriving in Hawai'i with their hosts in agricultural products during the early to mid 1800's, a period during which commerce with the rest of the world became firmly established. In our study, adventive species such as D. blackburni, $P$. puniceps, $V$. diminutus, T. flavoorbitalis, A. pallipes and Ichneumon cupitus were generally widespread and abundant, and comprised a large proportion of the total fauna. While most of the accidentally introduced species collected in our study are long-established in Hawai'i, the abundance of $V$. diminutus, an immigrant also found in India, south China and Japan, underscores the rapid rate at which alien parasitoids can spread throughout the state. It was first collected on Oahu in 1980 (Beardsley and Kumashiro 1990), and it now appears established on all of the main Hawaiian Islands, except perhaps Kaua'i and Lāna'i (Nishida 2002).

Impacts on native fauna, food webs, and ecosystems

Alien ichneumonoid parasitoids potentially attack a variety of Hawaiian arthropods, but the vast majority of the parasitoids collected in our traps attack various stages of immature Lepidoptera. The diversity and abundance of native Lepidoptera have decreased dramatically over the past century (Zimmerman 1978). It is exceedingly difficult, and in many cases too late, to identify causes of this decline, but increased rates of parasitism associated with the proliferation of alien parasitoids has long been implicated as being a major factor (Perkins 1897; Swezey 1954; Zimmerman 1948, 1970, 1978;
Howarth 1983). For example, Zimmerman (1948) discussed the vulnerability of Hawai'i's insular fauna to alien pressures, and suggested that "wholesale slaughter" of native Lepidoptera larvae by immigrant and introduced parasitoids led to once common moths now being rarely collected. More specifically, Gagné and Howarth (1982) speculated that seven species of Omiodes (Crambidae), some of which were common on banana (Musa $\times$ paradisiaca) at low elevation, may have been extirpated by parasitoids introduced for biocontrol. Other contributors to the demise of the Lepidoptera fauna are habitat degradation and loss of host plants (Gagné and Howarth 1982), and predation by alien ants (Zimmerman 1948, 1978) and the highly aggressive yellowjacket wasp (Vespula pensylvanica) (Gambino 1992).

Competitive pressures exerted by long-abundant alien ichneumonids, such as T. flavoorbitalis, Hyposoter exiguae and Casinaria infesta, have been implicated in the decline of the formerly rich assemblage of endemic Odynerus wasps (Vespidae), predators of native Lepidoptera larvae (Zimmerman 1948). The extent to which competitive pressures are exerted on native ichneumonids is unknown. There are few historical accounts describing the abundance of Hawaiian Ichneumonoidea prior to the introduction of most alien parasitoids, but Perkins (1907), upon conducting an entomological survey around the summit of Kîlauea volcano, adjacent to our CRA site, described the parasitic Hymenoptera fauna as "well represented by the usual Hawaiian types" with "ophions [i.e., Enicospilus] of various species and genera extremely numerous." Enicospilus may be particularly vulnerable to competition with alien parasitoids due to their tendency to attack late instars of larger Lepidoptera species. Like most Ophioninae, Enicospilus are thought to be parasitoids of nightfeeding Lepidoptera. In Hawai'i, late instars of Scotorythra larvae that feed primarily at night seem to be the preferred hosts of Enicospilus (Zimmerman 1958a). Because several smaller day-active species of parasitoids are known to attack Scotorythra (Zimmerman 1958b), it is probable that this host of Enicospilus is being usurped by other parasitoids attacking earlier instars that feed during the day. In fact, $H$. exiguae is a common parasitoid of several species of Scotorythra on Hawai'i Island, generally emerging from middle instars (USGS unpublished data). Although we did find E. orbitalis and three 
species within the endemic genus Spolas to be abundant at mid- and high-elevation sites, most other native species were uncommon or rare. In addition, we did not collect several endemic species with ranges reported to include our sites, including Banchogastra nigra (Ophioninae), Echthromorpha hawaiiensis (Pimplinae), and several other species of Spolas (Ashmead 1901; Perkins 1910). Considering our relatively intensive, long-termed trapping effort, it is plausible that these endemic species no longer exist in our study area.

Parasitoids are high-level consumers in food webs, and the domination of the Hawaiian parasitoid community by invasive species is likely to affect the structure and function of food webs and ecosystems in a variety of ways. For example, impacts of alien parasitoids on native Lepidoptera could secondarily affect plant-herbivore interactions, forest dynamics, and insectivore ecology. Herbivores such as Lepidoptera larvae may influence the vigor, reproduction, and demography of the plants they consume (Hawkes and Sullivan 2001), especially when plants are defoliated during insect outbreaks (Filion et al. 2006). The effects of insect herbivory on Hawaiian plants are largely unreported, except for occasional references to defoliation of Acacia koa forests by native Lepidoptera (Perkins 1913; Swezey 1954; Welton et al. 2004). Lepidoptera larvae are relatively easy to capture by forest birds, making them important prey for adult insectivores and critical food for the young of all species (Perkins 1903; Baldwin 1953; Ralph et al. 1985; Banko and Banko 1976, 2006). Our data indicate that Lepidoptera are more abundant in high-elevation habitats where endemic birds are also concentrated (Scott et al. 1986), although a variety of other factors are also considered to influence the distribution of Hawaiian forest birds (van Riper and Scott 2001). Adult Lepidoptera are important prey for the endangered Hawaiian Hoary bat (Lasirus cinereus semotus) (Belwood and Fullard 1984), thus changes in moth availability may also affect bat populations.

Multidisciplinary research is needed to further explore the scope and extent of impacts of alien parasitoids on Hawaiian ecosystems. In particular, we recommend surveys to determine the composition and dynamics of Lepidoptera communities along elevation gradients and in different habitats. Additionally, impacts of parasitoids and predaceous ants and wasps on Lepidoptera distribution and abundance should be investigated with rearing trials and experimental removals. Relevant to both ecological and commercial interests would be studies of factors that influence outbreaks of native caterpillars in Acacia koa forests. Studies to determine how native plants are affected by Lepidoptera herbivory would also provide valuable ecological insights. Finally, diet and foraging studies of birds and bats are needed to understand possible relationships between the distribution of endemic vertebrates, Lepidoptera, and parasitoid threats.

Acknowledgements This work was made possible by support from the National Science Foundation (NSF Grant \# DEB00-83944_ "Biocomplexity of Introduced Avian Disease in Hawai'i: Threats to Biocomplexity of Native Forest Ecosystems" to the University of Hawai'i at Mānoa) and by the U.S. Geological Survey's Terrestrial, Freshwater, and Marine Ecosystems Program and Invasive Species Program. The Biocomplexity Project was a collaboration of institutions, including U.S. Geological Survey-Pacific Island Ecosystems Research Center, U.S. Geological Survey-National Wildlife Health Center, University of Hawai'i at Hilo, University of Hawai'i at Mānoa, University of Wisconsin at Madison, Princeton University, and Smithsonian Institution. Kamehameha Schools, Hawai'i Division of Forestry and Wildlife, and Hawai'i Volcanoes National Park generously provided access to study sites. We thank C. Niwa for allowing us to use her malaise traps, R. Messing for helping identify Aphidiinae, B. Kumashiro for identifying some Ichneumonidae, and K. Voelke, C. J. Van Bers and D. Woods for their help in the field and in the lab. Comments from two anonymous reviewers improved an earlier draft of the manuscript. Any use of trade, product, or firm names in this publication is for descriptive purposes only and does not imply endorsement by the U.S. Government.

\section{References}

Ashmead WH (1901) Hymenoptera Parasitica. In: Sharp D (ed) Fauna Hawaiiensis. Cambridge University Press, Cambridge, England, pp 277-364

Askew RR (1971) Parasitic insects. Heinemann Educational Press, London, $316 \mathrm{pp}$

Askew RR, Shaw MR (1986) Parasitoid communities: their size, structure and development. In: Waage J, Greathead D (eds) Insect parasitoids. Academic Press, London, pp 225-264

Asquith A, Miramontes E (2001) Alien parasitoids in native forests: the ichneumonoid wasp community in a Hawaiian rainforest. In: Lockwood JA, Howarth FG, Purcell MF (eds) Balancing nature: assessing the impact of importing non-native biological control agents (an International perspective). Entomological Society of America, Lanham, pp 54-69 
Baldwin PH (1953) Annual cycle, environment and evolution in the Hawaiian honeycreepers (Aves: Drepaniidae). Univ Cal Publ Zool 52:285-398

Banko WE, Banko PC (1976) Role of food depletion by foreign organisms in historical decline of Hawaiian forest birds. In: Smith CW (ed) Proceedings of the first conference in natural sciences in Hawaii. Cooperative National Park Resources Studies Unit, University of Hawaii, Honolulu, pp 29-34

Banko PC, Banko WE (2006) Food specialization and radiation of Hawaiian honeycreepers. Acta Zool Sin 52(Supplement):253-256

Beardsley JW (1961) A review of the Hawaiian Braconidae (Hymenoptera). Proc Hawaiian Entomol Soc 17: 333-363

Beardsley JW, Kumashiro B (1990) Note on Vulgichneumon dimidiatus (Matsumura). Proc Hawaiian Entomol Soc 29:3

Beardsley JW, Perreira WD (2000) New distribution records for non-endemic Hymenoptera (Insecta) in Hawaii. Records of the Hawaii Biological Survey for 1999. Bishop Museum Occassional Papers 63:21-30

Belwood JJ, Fullard JH (1984) Echolocation and foraging behavior in the Hawaiian hoary bat, Lasiurus cinereus semotus. Can J Zool 62:2113-2120

Brenner GJ, Oboyski PT, Banko PC (2002) Parasitism of Cydia spp. (Lepidoptera: Tortricidae) on Sophora chrysophylla (Fabaceae) along an elevation gradient of dry subalpine forest on Mauna Kea, Hawaii. Pan-Pac Entomol 78: 101-109

Cushman RA (1944) The Hawaiian species of Enicospilus and Abanchogastra (Hymenoptera: Ichneumonidae). Proc Hawaiian Entomol Soc 12:39-56

Darling DC, Packer L (1988) Effectiveness of malaise traps in collecting Hymenoptera: The influence of trap design, mesh size, and location. Can Entomol 120:787-796

Edwards D, Berry JJ (1987) The efficiency of simulation-based multiple comparisons. Biometrics 43:913-928

Filion L, Payette S, Robert EC et al (2006) Insect-induced tree dieback and mortality gaps in high-altitude balsam fir forests of northern New England and adjacent areas. Ecoscience 13:275-287

Fluker SS, Beardsley JW (1970) Sympatric associations of three ants: Iridomyrmex humilis, Pheidole megacephala, and Anoplolepis longipes in Hawaii. Ann Entomol Soc Am 63:1290-1296

Follett PA, Duan J (1999) Nontarget effects of biological control. Kluwer, Boston, $316 \mathrm{pp}$

Follett PA, Duan J, Messing RH et al (2000) Parasitoid drift after biological control introductions: re-examining Pandora's box. Am Entomol 46:82-94

Funasaki GY, Lai P-Y, Nakahara LM et al (1988) A review of biological control introductions in Hawaii: 1890-1985. Proc Hawaiian Entomol Soc 28:105-160

Gagné WC (1979) Canopy-associated arthropods in Acacia koa and Metrosideros tree communities along an altitudinal transect on Hawaii Island. Pac Insects 21:56-82

Gagné WC, Howarth FG (1982) Conservation status of endemic Hawaiian Lepidoptera. In: Proceedings of the 3rd congress on European lepidopterology, Cambridge, 1982. Soc Eur Lepid, Karlsruhe, pp 74-84
Gambino P (1992) Yellowjacket (Vespula pensylvanica) predation at Hawaii Volcanoes and Haleakala National Parks: identity of prey. Proc Hawaiian Entomol Soc 31:157-164

Gaston KJ, Gauld ID (1993) How many species of pimplines (Hymenoptera: Ichneumonidae) are there in Costa Rica? J Trop Biol 9:491-499

Gauld ID (1986) Latitudinal gradients in ichneumonid speciesrichness in Australia. Ecol Entomol 11:155-161

Gauld ID (1987) Some factors affecting the composition of tropical ichneumonid faunas. Biol J Linn Soc 30:299-312

Giambelluca TW, Nullet MA, Schroeder TA (1986) Rainfall atlas of Hawaii. State of Hawaii, Department of Land and Natural Resources, Division of Water and Land Development, Honolulu, 267 pp

Gillespie RG, Reimer N (1993) The effect of alien predatory ants (Hymenoptera: Formicidae) on Hawaiian endemic spiders (Araneae: Tetragnathidae). Pac Sci 47:21-33

Green PT, O’Dowd DJ, Lake PS (1999) Alien ant invasion and ecosystem collapse on Christmas Island, Indian Ocean. Aliens 9:2-4

Haines IH, Haines JB, Cherrett JM (1994) The impact and control of the crazy ant, Anoplolepis longipes (Jerd.), in the Seychelles. In: Williams DF (ed) Exotic ants: biology, impact and control of introduced species. Westview Press, Boulder, pp 206-218

Hawkes CV, Sullivan JJ (2001) The impact of herbivory on plants in different resource conditions: a meta-analysis. Ecology 82:2045-2058

Henneman ML, Memmott J (2001) Infiltration of a Hawaiian community by introduced biological control agents. Science 293:1314-1316

Howarth FG (1983) Classical biological control: panacea or Pandora's box. Proc Hawaiian Entomol Soc 24:239-244

Howarth FG (1991) Environmental impacts of classical biological control. Ann Rev Entomol 36:485-509

Insightful Corporation (1988-2005). S-PLUS version 7.0 for Windows (computer software). Insightful Corporation, Seattle

Janzen DH (1981) The peak in North American Ichneumonid species richness lies between $38^{\circ}$ and $48^{\circ} \mathrm{N}$. Ecology 62:532-537

Janzen DH, Pond CM (1975) A comparison by sweep sampling of the arthropod fauna of secondary vegetation in Michigan, England, and Costa Rica. Trans R Entomol Soc Lond 127:33-50

Johnson MW, Mitchell WC, Robin MR et al (1988) Parasitization of the Diamondback moth, Plutella xylostella (L.) (Lepidopetra: Plutellidae), in Hawaii. Proc Hawaiian Entomol Soc 28:197-203

Johnson MT, Follett PA, Taylor AD et al (2005) Impacts of biological control and invasive species on a non-target native Hawaiian insect. Oecologia 142:529-540

Juvik SP, Juvik JO (1998) Atlas of Hawai'i, 3rd edn. University of Hawai'i Press, Honolulu, HI, 333 pp

Laman TG (1995) Safety recommendations for climbing rain forest trees with "single rope technique". Biotropica 27:406-409

Lester PJ, Tavite A (2004) Long-legged ants, Anoplolepis gracilipes (Hymenoptera: Formicidae), have invaded Tokelau, changing composition and dynamics of ant and invertebrate communities. Pac Sci 58:391-401 
Mathews RW, Mathews JR (1983) Malaise traps: the Townes model catches more insects. Contrib Am Entomol Inst 20:428-432

Munro VMW, Henderson IM (2002) Nontarget effect of entomophagous biocontrol: shared parasitism between native lepidopteran parasitoids and the biocontrol agent Trigonospila brevifacies (Diptera: Tachinidae) in forest habitats. Environ Entomol 31:388-396

Nishida GM (2002) Hawaiian terrestrial arthropod checklist. Technical Report 22, Bishop Museum, Honolulu, Hawaii, $313 \mathrm{pp}$

Noyes JS (1989) The diversity of Hymenoptera in the tropics with special reference to Parasitica in Sulawesi. Ecol Entomol 14:197-207

Oboyski PT, Slotterback JW, Banko PC (2004) Differential parasitism of seed-feeding Cydia (Lepidoptera: Tortricidae) by native and alien wasp species relative to elevation in subalpine Sophora (Fabaceae) forests on Mauna Kea, Hawaii. J Insect Conserv 8:220-240

Owen DF, Owen J (1974) Species diversity in temperate and tropical Ichneumonidae. Nature 249:583-584

Owen J, Townes H, Townes M (1981) Species diversity of Ichneumonidae and Serphidae (Hymenoptera) in an English suburban garden. Biol J Linn Soc 16:315-336

Perkins RCL (1897) The introduction of beneficial insects into the Hawaiian Islands. Nature 55:499-500

Perkins RCL (1903) Vertebrata. In: Sharp D (ed). Fauna Hawaiiensis, vol 1, part IV. Cambridge University Press, Cambridge, England

Perkins RCL (1907) Insects at Kilauea, Hawaii. Proc Hawaiian Entomol Soc 1:89-99

Perkins RCL (1910) Hymenoptera (supplement). In: Sharp D (ed) Fauna Hawaiiensis. Cambridge University Press, Cambridge, pp 600-686

Perkins RCL (1913) Introduction. In: Sharp D (ed) Fauna Hawaiiensis. Cambridge University Press, Cambridge, pp xv-cexxviii

Ralph CP, Ralph CJ, Nagata SE (1985) Analysis of droppings to describe diets of small birds. J Field Ornith 56:165-174

Sääksjärvi IE, Haataja S, Neuvonen S et al (2004) High local species richness of parasitic wasps (Hymenoptera: Ichneumonidae; Pimplinae and Rhyssinae) from the lowland rainforests of Peruvian Amazonia. Ecol Entomol 29:735-743

Scott JM, Mountainspring S, Ramsey FL et al (1986) Forest bird communities of the Hawaiian Islands: their dynamics, ecology, and conservation. Stud Av Biol 9:1-431
Sharkey MJ (1993) Family Braconidae. In: Goulet H, Huber JT (eds) Hymenoptera of the world: an identification guide to families. Canada Communication Group, Ottawa, pp 362395

Swezey OH (1954) Forest Entomology in Hawaii. B.P. Bishop Museum Special Publication 44, Honolulu, 266 pp

Townes H (1972) A light-weight Malaise trap. Entomol News 83:239-247

van Riper C III, Scott JM (2001) Limiting factors affecting Hawaiian native birds. Stud Av Biol 22:221-233

Wahl DB (1993) Family Ichneumonidae. In: Goulet H, Huber JT (eds) Hymenoptera of the world: an identification guide to families. Canada Communication Group, Ottawa, pp 395-448

Wahl DB, Sharkey MJ (1993) Superfamily Ichneumonoidea. In: Goulet H, Huber JT (eds) Hymenoptera of the world: an identification guide to the families. Canada Communication Group, Ottawa, pp 358-362

Welton P, Anderson KD, Del Real C et al (2004) Defoliation of koa (Acacia koa) at Haleakala National Park, Maui, due to the vascular wild fungus Fusarium oxysporum f. sp koae and/or the endemic moth, Scotorythra paludicola? In: Paper presented at the Hawai'i conservation conference, Honolulu, HI, 29-30 June 2004

Williams FX (1931) Handbook of the insects and other invertebrates of Hawaiian sugar cane fields. Advertiser Publ., Honolulu, 400 pp

Wolfe EW, Morris J (1996) Geologic map of the Island of Hawaii. Miscellaneous investigations series map I-2524A. US Geological Survey, Reston

Woodworth BL, Atkinson CT, LaPointe DA et al (2005) Host population persistence in the face of introduced vectorborne diseases: Hawaii amakihi and avian malaria. Proc Natl Acad Sci 102:1531-1536

Zimmerman EC (1948) Insects of Hawaii, vol 1: Introduction. University of Hawaii Press, Honolulu, 206 pp

Zimmerman EC (1958a) Insects of Hawaii, vol 8: Lepidoptera: Pyraloidea. University of Hawaii Press, Honolulu, 456 pp

Zimmerman EC (1958b) Insects of Hawaii, vol 9: Macrolepidoptera. University of Hawaii Press, Honolulu, 542 pp

Zimmerman EC (1970) Adaptive radiation in Hawaii with special reference to insects. Biotropica 2:32-38

Zimmerman EC (1978) Insects of Hawaii, vol 9: Microlepidoptera. University of Hawaii Press, Honolulu, 1903 pp 